\title{
Heterosis and Combining Ability Studies for Yield and Yield Component Traits in Rice (Oryza sativa L.)
}

\author{
K. Sudeepthi*, D.P.B. Jyothula and Y. Suneetha \\ Department of Genetics and Plant Breeding, Agricultural College Bapatla, \\ Andhra Pradesh, India \\ *Corresponding author
}

\section{A B S T R A C T}

\section{Keywords}

Line $\mathrm{x}$ Tester, Combining ability, Heterosis, Hybrid rice

Article Info

Accepted:

10 September 2018

Available Online:

10 October 2018
The present investigation was carried during Kharif 2015-16 at Agricultural College Farm, Bapatla to estimate the combining ability and to determine the nature and magnitude of heterosis for yield and yield component traits in rice. The experimental material consisted of 21 hybrids produced by crossing three cytoplasmic male sterile lines with seven elite testers in Line $x$ Tester design. The magnitude of combining ability revealed both additive and non-additive gene action were found to control the expression of the traits under study, however non-additive genetic variance was higher than the additive variance for all the studied traits except for test weight. Among parents, CMS line IR 58025A and testers NLR 33654, NLR 3083 were found to be promising good general combiners for grain yield plant $^{-1}$ and other traits. Three crosses were found to be desirable for grain yield plant ${ }^{-1}$ where in the cross IR 58025A x NLR 33057 recorded significant $s c a$ effects for majority of the characters viz., days to $50 \%$ flowering, days to maturity, plant height, number of productive tillers plant $^{-1}$, number of filled grains panicle ${ }^{-1}$ and grain yield plant ${ }^{-1}$. None of the hybrids recorded significant $s c a$ effects for all the eight characters.

\section{Introduction}

Rice has been one of the world's most important food crops, feeding more than half of the world's population (Khush, 1997). In Asia and Pacific region, rice is the main staple food and the most important source of employment and income for rural people.

The rice productivity has reached a plateau so it is thus imperative to find alternative means for increasing the yield potential of rice cultivars in a sustainable manner. Of the various approaches contemplated to break the existing yield barriers in rice, hybrid rice technology offers an opportunity to boost the yield of rice under fragile conditions as hybrid rice varieties have a yield advantage of 15 $20 \%$ over the conventional high yielding varieties (Virmani et al., 1996). Breeding strategies for developing hybrids with high yield potential and better grain quality require the expected level of heterosis and combining ability. Knowledge of combining ability and heterosis helps in the selection of appropriate parents for a hybridization programme for evolving elite segregants with high grain yield in the segregating generations. Heterosis 
breeding is an important tool which can facilitate yield enhancement and helps enrich many other desirable quantitative traits in rice In order to exploit maximum heterosis using the CMS system in a hybrid programme, one must know the combining ability of different male sterile lines and testers. The knowledge of combining ability allows the assessment of nicking ability among genotypes and understanding the nature and magnitude of gene actions involved. Its role is important to decide parents, crosses and appropriate breeding procedures to be followed to select desirable segregants.

\section{Materials and Methods}

A field experiment was conducted at Agricultural College Farm, Bapatla during Kharif 2015-16 with 21 hybrids generated from crossing three lines (IR 58025A, IR 68888A and IR 68897A) and seven testers (NLR 40065, NLR 33564, NLR 33057, NLR 3083, NLR 3042, NLR 3449 and WGL 44) in $\mathrm{L} \times \mathrm{T}$ fashion along with ten parents and two checks DRRH 2 (hybrid) and MTU 1010 (varietal check) in a randomized block design with two replications. One month old seedlings were transplanted in thoroughly puddled main field with a spacing of $20 \times 15$ $\mathrm{cm}$. All necessary precautions were taken to maintain uniform plant population in each treatment per replication. Observations were recorded on 10 randomly selected plants from each cross for eight metric traits viz., plant height $(\mathrm{cm})$, number of productive tillers per plant, panicle length $(\mathrm{cm})$, number of filled grains panicle $^{-1}$, test weight $(\mathrm{g})$, grain yield plant $^{-1}(\mathrm{~g})$ in each replication. Days to $50 \%$ flowering and days to maturity were recorded on plot basis. Heterosis was estimated over better parent and standard check and tested for significance as suggested by Snedecor and Cochran (1967) and combining ability analysis was computed using Line $\mathrm{x}$ Tester design according to Kempthorne (1957).

\section{Results and Discussion}

The analysis of variance for combining ability revealed highly significant differences among the crosses with respect to all the characters studied (Table 1). The ratio of GCA and SCA variance was less than unity for all the characters except for test weight indicated preponderance of non-additive gene action for majority of characters. These results are in concordance with Savita et al., (2015) for Days to $50 \%$ flowering, Sateeshkumar and Sarvanan (2013) for Days to Maturity, Sathya and Jebaraj (2015) for plant height, Savita et al., (2015) for number of productive tillers plant $^{-1}$, Kishor et al., (2017) for panicle length, Ali et al., (2014) for number of filled grains panicle $^{-1}$, Devi et al., (2017) for grain yield plant $^{-1}$. Additive gene action for test weight had been reported by Ali et al., (2014). The presence of greater magnitude of non-additive gene action offers scope for exploiting hybrid vigour through heterosis breeding.

The estimates of gca effects of parents showed that IR 58025A and testers NLR 33654, NLR 3083 were found to be promising good general combiners for grain yield plant $^{-1}$ and other yield component traits. The line IR 58025A recorded significant $g c a$ effects in desirable direction for grain yield plant $^{-1}$ and line IR 68897A recorded significant gca effects in desirable direction for characters like days to $50 \%$ flowering, days to maturity, number of productive tillers plant ${ }^{-1}$ and test weight while the tester NLR 33654 recorded significant gca effects in desirable direction for majority of the characters viz., days to maturity, plant height, productive tillers plant $^{-1}$, panicle length, filled grains panicle ${ }^{-1}$ and grain yield plant $^{-1}$.

\section{Evaluation of hybrids based on sca effects}

The second important criterion for the evaluation of hybrids is the specific combining 
ability effects which could be related with hybrid vigour. The sca effects signify the role of non-additive gene action in trait expression. According to Ping and Virmani (1990), sca effects are the index to determine the usefulness of a particular cross combination for exploitation of heterosis. Out of 21 crosses the cross IR 58025A x NLR 33057 recorded significant sca effects for majority of the characters viz., days to $50 \%$ flowering, days to maturity, plant height, number of productive tillers plant ${ }^{-1}$, number of filled grains panicle ${ }^{-1}$ and grain yield plant ${ }^{-1}$. Ranking of parents with respect to general combining ability effects for grain yield and yield component characters in addition to number of hybrids exhibiting significant and desirable sca effects for the different traits shown in Table 2. The negative estimates of sca effects are desirable for earliness and medium dwarf plant height. Five hybrids viz.IR 58025A x NLR 40065(3.29**), IR 68888A x NLR 33654 (3.34**), IR 68897A x NLR 33654 (5.90**), IR 58025A x NLR 33057 (7.51**) and IR 58025A x NLR $3042(4.68 * *)$ showed significant sca effects for grain yield plant ${ }^{-1}$. Similarly 8 hybrids for Days to $50 \%$ flowering, 5 hybrids for days to maturity, 4 hybrids for number of productive tillers plant ${ }^{-1}, 6$ hybrids each for traits filled grains plant ${ }^{-1}$ and test weight and single hybrid each for traits plant height IR 58025A x NLR 33057(-6.08**) and panicle length IR 68897A x NLR $3042(0.99 *)$ showed significant sca effects in desirable direction. Predominance of non-additive gene action for grain yield and its components was also reported by Dalvi and Patel (2009), Saidaiah et al., (2011) and Tiwari et al., (2011).

A hybrid is commercially valuable only when it exhibits significantly high standard heterosis over the best locally adopted variety or hybrid. Biju et al., (2006), reported the presence of exploitable level of heterosis is yet another pre - requisite for the success of hybrid breeding and is recognized as the genetic tool in yield ceiling areas where yields have already approached their potential. In the present study, the hybrids were evaluated based on the two types of heterosis i.e. Heterobeltiosis (over better parent) and Standard heterosis (Over hybrid check DRRH2). The range of heterosis, number of desirable heterotic hybrids and best hybrid combination for each trait were depicted in Table 3.

No desirable heterotichybrid was found for the trait panicle length for both heterobeltiosis and standard heterosis. Similar result reported by Krishna et al., (2011) and Singh et al., (2015) respectively. For the trait grain yield plant ${ }^{-1} 3$ hybrids were found to be desirable for standard heterosis showing a range of -77.27 to 59.44. None of the hybrid was found to be desirable for trait grain yield per plant for heterobeltiosis.

High sca effects alone may not be the appropriate choice for heterosis exploitation because hybrids with low mean values may also possess high sca effects. Further, heterosis value alone may also mislead the identity of superior hybrids. Exploitation of hybrids for heterosis breeding is best judged by per se, sca effects and magnitude of heterosis, characteristics of parents with regards to $g c a$ effects for grain yield plant $^{-1}$ and component characters (Table 4). Based on these criteria the hybrids IR 68897A x NLR 33654, IR 58025A x NLR 33057, IR 68888A $x$ NLR 33654 and IR 68897A x NLR 3083 were found to be suitable for heterosis breeding.

Considering the hybrid IR 68897A $x$ NLR 3083 showing non-significant sca effect with favourable gca effects of parents is suitable for recombination breeding to get desirable segregants in early segregating generations for yield attributes. These results are in support with findings of Sheeba et al., (2010) and Sathya and Jebaraj (2015). 
Table.1 Analysis of variance for combining ability for yield and yield component traits in rice hybrids (Oryza sativa L.)

\begin{tabular}{|c|c|c|c|c|c|c|c|c|c|}
\hline $\begin{array}{l}\text { Source of } \\
\text { variation }\end{array}$ & d.f & $\begin{array}{l}\text { Days to } 50 \% \\
\text { Flowering }\end{array}$ & $\begin{array}{l}\text { Days to } \\
\text { maturity }\end{array}$ & $\begin{array}{l}\text { Plant } \\
\text { Height } \\
\text { (cm) }\end{array}$ & $\begin{array}{l}\text { Number of } \\
\text { Productive tillers } \\
\text { plant }^{-1}\end{array}$ & $\begin{array}{l}\text { Panicle length } \\
\text { (cm) }\end{array}$ & $\begin{array}{l}\text { Number of Filled } \\
\text { grains panicle }^{-1}(\mathrm{~g})\end{array}$ & $\begin{array}{l}\text { Test weight } \\
\text { (g) }\end{array}$ & $\begin{array}{l}\text { Grain yield } \\
\text { plant }^{-1}(g)\end{array}$ \\
\hline Replication & 1 & 0.095 & 1.52 & 0.02 & 0.30 & 0.10 & 1.30 & 0.09 & 0.16 \\
\hline Treatments & 30 & $92.84^{* *}$ & $50.86^{* *}$ & $156.13^{* *}$ & $7.20^{* *}$ & $3.86^{* * *}$ & $1355.95^{* *}$ & $12.71^{* *}$ & $79.00^{* *}$ \\
\hline Parents & 9 & $84.13^{* *}$ & $76.71^{* *}$ & $316.09^{* *}$ & $8.75^{* *}$ & $9.44^{* * *}$ & $1943.85^{* *}$ & $21.16^{* *}$ & $139.21^{* *}$ \\
\hline Parents vsCrosses & 1 & $320.88^{* *}$ & $196.37^{* *}$ & $1023.55^{* *}$ & 0.66 & $2.72^{*}$ & 14.61 & $6.89^{* *}$ & $34.61^{* *}$ \\
\hline Crosses & 20 & $85.36^{* *}$ & $31.95^{* *}$ & $40.78^{* *}$ & $6.84^{* *}$ & $1.40^{* *}$ & $1158.46^{* *}$ & $9.19^{\text {** }}$ & $54.13^{* *}$ \\
\hline Lines & 2 & $77.16^{* *}$ & $70.16^{* *}$ & $156.68^{* *}$ & $4.58^{*}$ & $2.54^{* *}$ & $157.12^{*}$ & $11.23^{* *}$ & 0.06 \\
\hline Testers & 6 & $33.11^{* *}$ & $35.28^{* *}$ & $320.34^{* *}$ & $10.25^{* *}$ & $13.31^{* *}$ & $2738.68^{* * *}$ & $23.00^{* *}$ & $31.35^{* *}$ \\
\hline Lines vstesters & 1 & $404.15^{* *}$ & $338.40^{* *}$ & $609.46^{* *}$ & $8.12^{*}$ & 0.03 & $748.26^{* *}$ & $30.01^{* *}$ & $1064.66^{* *}$ \\
\hline Error & 30 & 1.09 & 1.02 & 4.19 & 0.58 & 0.25 & 5.67 & 0.11 & 1.36 \\
\hline$\sigma^{2} \mathrm{GCA}$ & & 12.06 & 4.59 & 4.93 & 0.83 & 0.10 & 81.23 & 1.85 & 3.42 \\
\hline$\sigma^{2} \mathrm{SCA}$ & & 36.89 & 10.78 & 7.53 & 2.85 & 0.33 & 543.09 & 1.55 & 28.26 \\
\hline$\sigma^{2}$ GCA/SCA & & 0.32 & 0.42 & 0.65 & 0.29 & 0.30 & 0.14 & 1.19 & 0.12 \\
\hline
\end{tabular}

Table.2 Ranking of parents with respect to general combining ability effects for grain yield and yield components characters in addition to number of hybrids exhibiting significant and desirable sca effects for the different traits in rice

\begin{tabular}{|c|c|c|c|c|c|c|c|c|c|c|c|c|}
\hline $\begin{array}{c}\text { S } \\
\text { No }\end{array}$ & TRAITS & $\begin{array}{c}\mathrm{IR} \\
58025 \mathrm{~A}\end{array}$ & $\begin{array}{c}\text { IR } \\
\text { 68888A }\end{array}$ & $\underset{\text { 68897A }}{\mathrm{IR}}$ & $\begin{array}{l}\text { NLR } \\
40065\end{array}$ & $\begin{array}{l}\text { NLR } \\
33654\end{array}$ & $\begin{array}{l}\text { NLR } \\
\mathbf{3 3 0 5 7}\end{array}$ & $\begin{array}{c}\text { NLR30 } \\
\mathbf{8 3}\end{array}$ & $\begin{array}{c}\text { NLR34 } \\
49\end{array}$ & $\begin{array}{l}\text { NLR } \\
3042\end{array}$ & $\begin{array}{c}\text { WGL } \\
44\end{array}$ & $\begin{array}{l}\text { No. of hybrids } \\
\text { with significant } \\
\text { sca effects }\end{array}$ \\
\hline 1 & DFF & Low & Low & High & Low & Low & High & Low & High & High & High & 8 \\
\hline 2 & DM & Low & Low & High & Low & Low & High & Low & Low & High & High & 5 \\
\hline 3 & PH & Low & Low & Low & Low & Low & Low & Low & High & High & High & 1 \\
\hline 4 & EBT & Low & Low & High & Low & High & Low & High & Low & Low & High & 5 \\
\hline 5 & PL & Low & Low & Low & Low & High & High & Low & Low & Low & Low & 1 \\
\hline 6 & FGP & Low & Low & Low & Low & High & Low & Low & High & Low & Low & 6 \\
\hline 7 & TW & Low & Low & High & Low & Low & High & High & Low & Low & High & 5 \\
\hline 8 & GYP & High & Low & Low & Low & High & Low & High & Low & Low & Low & 5 \\
\hline
\end{tabular}

$\mathrm{DFF}=$ Days to $50 \%$ flowering, DM= Days to maturity, Plant Height, EBT= Number of Productive tillers per plant, $\mathrm{PL}=$ Panicle length, FGP= Number of Filled grains per panicle, $\mathrm{TW}=$ Test weight, $\mathrm{GYP}=$ Grain Yield Plant ${ }^{-1}$ 
Table.3 Heterobeltiosis and Standard heterosis for grain yield and yield component characters in Rice

\begin{tabular}{|c|c|c|c|c|c|c|c|}
\hline S No. & Character & \multicolumn{3}{|c|}{ Heterobeltiosis } & \multicolumn{3}{|c|}{ Standard heterosis } \\
\hline & & Range & $\begin{array}{c}\text { No. of } \\
\text { desirable } \\
\text { heterotic } \\
\text { hybrids }\end{array}$ & Best hybrid combination & Range & $\begin{array}{c}\text { No. of } \\
\text { desirable } \\
\text { heterotic } \\
\text { hybrids }\end{array}$ & Best hybrid combination \\
\hline 1 & DFF & -18.36 to 6.81 & 18 & IR 68897A x NLR 3083 & -11.05 to 12.71 & 17 & IR 68888A x NLR 33057 \\
\hline 2 & $\mathrm{DM}$ & -11.15 to -2.3 & 18 & IR 68897A x NLR 3083 & -10.71 to -4.37 & 17 & IR 68897A x NLR 3042 \\
\hline 3 & $\mathrm{PH}$ & -27.95 to 6.46 & 18 & IR 58025A x NLR 33057 & -23.10 to -6.81 & 21 & IR 68888A x NLR 3449 \\
\hline 4 & EBT & -31.46 to 19.75 & 4 & IR 58025A x NLR 33057 & -25 to 23.91 & 4 & IR 68897A x NLR 33654 \\
\hline 5 & PL & -14.44 to-5.93 & 0 & 0 & -13.81 to -6.5 & 0 & - \\
\hline 6 & FGP & -40.80 to 54.71 & 6 & IR 68897A x NLR 33654 & -24.83 to 69.03 & 15 & IR 68897A x NLR 33654 \\
\hline 7 & TW & -29.96 to 10.28 & 1 & IR 68888A x NLR 3083 & -20.30 to 21.95 & 8 & IR 68897A x WGL 44 \\
\hline 8 & GYP & -81.53 to -11.14 & 0 & 0 & -77.27 to 59.44 & 3 & IR 68897A x NLR 33654 \\
\hline
\end{tabular}

$\mathrm{DFF}=$ Days to $50 \%$ flowering, DM= Days to maturity, Plant Height, EBT= Number of Productive tillers per plant, PL= Panicle leng th, FGP= Number of Filled grains per panicle, $\mathrm{TW}=$ Test weight, GYP= Grain Yield Plant ${ }^{-1}$

Table.4 Details of the promising hybrids identified for grain yield per plant in rice

\begin{tabular}{|c|c|c|c|c|c|c|}
\hline Cross combination & $\begin{array}{l}\text { Per se } \\
\text { performance }\end{array}$ & Heterobeltiosis & $\begin{array}{l}\text { Standard } \\
\text { heterosis } \\
\text { (DRRH2) }\end{array}$ & sca effect & $\begin{array}{l}\text { Characteristi } \\
\text { cs of parents } \\
\text { with regards } \\
\text { to gca effects }\end{array}$ & $\begin{array}{c}\text { Desirable per se heterosis and sca effects for } \\
\text { yield component characters }\end{array}$ \\
\hline $\begin{array}{c}\text { IR 68897A x NLR } \\
33654 \\
\end{array}$ & 22.80 & 3.64 & $59.44 * *$ & $5.90 * *$ & $\mathrm{~L} \times \mathrm{H}$ & $\begin{array}{l}\text { Number of Productive tillers plant }{ }^{-1} \text {, Number } \\
\text { of filled grains panicle }\end{array}$ \\
\hline $\begin{array}{l}\text { IR 58025A x NLR } \\
33057\end{array}$ & 20.80 & 3.48 & $45.45^{* *}$ & $7.51 * *$ & $\mathrm{H} \times \mathrm{L}$ & $\begin{array}{c}\text { Days to } 50 \% \text { flowering, Days to maturity, Plant } \\
\text { Height, Number of filled grains panicle }{ }^{-1}\end{array}$ \\
\hline $\begin{array}{l}\text { IR 68888A x NLR } \\
33654\end{array}$ & 19.55 & $-11.14 *$ & $36.71 * *$ & $3.34 * *$ & $\mathrm{~L} \times \mathrm{H}$ & Days to $50 \%$ flowering, Days to maturity \\
\hline $\begin{array}{l}\text { IR 68897A x NLR } \\
3083\end{array}$ & 17.50 & $-17.84 * *$ & $22.38 * *$ & 2.73 & $\mathrm{~L} \times \mathrm{H}$ & Days to $50 \%$ flowering, Days to maturity \\
\hline
\end{tabular}


In the crosses showing high SCA effects due to high $\times$ low general combiners, simple pedigree breeding would not be effective to improve the characters. Population improvement i.e. mass selection with concurrent random mating in early segregating generations could be a perspective breeding procedure for yield improvement in rice.

The GCA and SCA results indicated importance of both additive and dominance genetic components in the inheritance. The lines IR 58025A and IR 68897A and tester NLR 33654 recorded significant $g c a$ effects in desirable direction for majority of the characters. Therefore these genotypes can be utilized in improvement of the respective traits in any breeding programme. Due to good combining ability these genotypes can also be utilized straightaway as parents for production of good hybrids by crossing with other divergent lines.

\section{References}

Ali, M., Mian, M.A.K., Hossain, M.A., Islam, M.Z and Manzur, H.M. 2014. Combining ability and heterosis in quasi aromatic rice (Oryza sativa L.). Bangladesh Journal of Plant Breeding and Genetics. 27 (1): 01-08.

Archana, D., Preeti, K., Ranjan, D., Saket, D., Verma, O.P., Singh, P.K and Dwivedi, D.K. 2017. Studies on heterosis and combining ability in rice (Oryza sativa) for morpho-physiological traits under normal and saline conditions. International Journal of Current Microbiology and Applied Sciences. 6(8): 1558-1571.

Biju, S., Manonmani, S., Thiyagarajan, K., Thiyagu, K., Abirami, S and Mohanasundram, K. 2006. Studies on heterosis for yield and related characters in rice hybrids. Plant Archives. 6(2): 549-551.

Dalvi VV, Patel DV. 2009. Combining ability analysis for yield in hybrid rice. Oryza, 46-(2), 97-102.

Kempthorne, O. 1957. An Introduction to Genetic Statistics.John Wiley and Sons Publishing Co. Pvt. Ltd., New York. 458-471.

Khush, G. S. 1997. Breaking the yield barrier of rice. Geo Journal. 35: 329-332.

Kishor, R., Devi, A., Preeti, K., Saket, D., Ranjan, D., Giri, S.P., Dwivedi, D.K and Pandey, U.P. 2017. Gene action and combining ability in rice (Oryza sativa) involving indica and tropical japonica. International Journal of Current Microbiology and Applied Sciences. 6(7): 8-16.

Krishna, L., Raju, Ch.D., Raju, Ch.S., Vanisree, S., Reddy, N.P and Reddy, B.B. Heterosis for yield and quality traits in Rice (Oryza sativa L.). Madras Agricultural Journal 98 (4-6): 109-112.

Ping, J.Y. and Virmani, S.S. 1990. Combining ability for yield and four related traits in relation to breeding in rice. Oryza, 27: 1-10.

Rahimi, M., Rabiei, B., Samizadeh, $\mathrm{H}$ and Kafighasemi, A. 2010. Combining ability and heterosis in rice (Oryza sativa L.) cultivars. Journal of Agricultural Science and Technology. 12: 223-231.

SaidaiahP, Sudheer Kumar S, Ramesha MS. 2011. Combining ability studies for development of new hybrids in rice over environments. Journal of Agricultural Sciences (2): 225-233.

Satheeshkumar, P and Saravanan, K. 2013. Studies on combining ability for yield attributes in rice (Oryza sativa L.). International Journal of Current Agricultural Research. 2 (12): 56-58.

Sathya, R and Jebaraj, S. 2015. Evaluation of aerobic hybrid analysis of combining 
ability in three line hybrids in rice (Oryza sativa L.) under aerobic conditions. African Journal of Agricultural Research.10 (18): 19711981.

Sheeba, A., Vivekanandan, P., Banumathy, S., Manimaran, $\mathrm{R}$ and Ramasubramanian, G.V. 2010. Role of secondary and putative traits for improvement of upland rice. Electronic Journal of Plant Breeding. 1(4): 903907.

Singh, A.K., Mall, A.K., Singh, P.K., Singh, S., Singh, A.K and Verma, O.P 2015. Genetic architecture, heterosis and inbreeding depression for yield and yield associated physiological traits in rice (Oryza sativa L.) under drought condition. SAARC Journal of Agriculture. 13(1):50-62.

Snedecor, G.W and Cochran, W.G. 1967. Statistical Methods. The Iowa State College Press, Ames, Iowa. U.S.A. 160413.

Tiwari DK, Pandey P, Giri SP, Dwivedi JL. 2011. Prediction of gene action, heterosis and combining ability to identify superior rice hybrids. Int. J. Bot, 7: 126-144.

Virmani SS (1996). Hybrid Rice. Advances in Agronomy. Pp. 377-462.

\section{How to cite this article:}

Sudeepthi, K., D.P.B. Jyothula and Suneetha, Y. 2018. Heterosis and Combining Ability Studies for Yield and Yield Component Traits in Rice (Oryza sativa L.). Int.J.Curr.Microbiol.App.Sci. 7(10): 1205-1211. doi: https://doi.org/10.20546/ijcmas.2018.710.134 